\title{
The Effects of Intracerebroventricular Administration of Tonin on Water Drinking and Blood Pressure in Rats
}

\author{
KaZUOKi KONDO and TAKao SARUTA \\ Department of Internal Medicine, School of Medicine, Keio \\ University. Shinanomachi, Shinjuku-ku, Tokyo 160, Japan \\ RAUl GARCIA AND Roger BOUCHER \\ Clinical Research Institute of Montreal. 110 Pine \\ Avenue West, Montreal, Quebec, Canada
}

\begin{abstract}
Intraventricular administration of tonin, an enzyme which forms angiotensin II directly from a natural protein substrate (angiotensinogen), stimulated water drinking and increased systemic blood pressure in rats. These responses were abolished by the simultaneous administration of an angiotensin II analogue, but unaffected by an angiotensin I- converting enzyme inhibitor. We confirmed, in vitro, that angiotensin II was generated when the brain homogenate was incubated with tonin in the presence of DFP and EDTA. These results indicate that the central effects of tonin on water drinking and systemic blood pressure are mediated via the direct formation of angiotensin II in the brain, and suggest the possibility that the tonin-angiotensin II system in the central nervous system might be important in controlling water balance and blood pressure.
\end{abstract}

A recently described specific enzyme called tonin forms angiotensin II directly from a natural protein, the renin tetradecapeptide substrate and also from angiotensin I (Boucher et al., 1974 and 1977). On the basis of the presence in plasma of a strong protein inhibitor, it has been suggested that tonin may play an important role in the local generation of angiotensin II in tissues. Recent evidence strongly indicates that this enzyme is involved in the pathogenesis of hypertension by the local formation of angiotensin II (Kondo et al., 1977; Boucher et al., 1978; Garcia et al., 1978).

It has been suggested that angiotensin II, which is generated locally within the brain, acts directly on the central nervous system and regulates water drinking and blood pressure (Smookler et al,, 1966 ; Epstein etal., 1970 ; Fisher-Ferraro et al., 1971;

Received January 17, 1980.
Ganten et al., 1971; Ganten and Speck, 1978). Previous observations have demonstrated that intracranial administration of renin induced drinking and an increase in blood ressure (Epstein et al., 1974; Reid and Ramsay, 1975; Ganten and Speck, 1978). In this study, we examined the effects of intraventricularly administered tonin on drinking and blood pressure, and tried to find out whether these effects were mediated via the direct formation of angiotensin II by this enzyme in the brain.

\section{Materials and Methods}

Male Sprague-Dawley rats, weighing around $300 \mathrm{~g}$ were used in these experiments.

[In vivo experiments]

Intraventricular cannulation was performed under pentobarbital anesthesia (pentobarbital sodium, $50 \mathrm{mg}$ / $\mathrm{kg}$, i.p.) according to the method of Donaldson et al. (1971). After the implantation of intraventricular cannulae the rats were kept in individual metabolism 
cages and food and water were available ad libitum. All tested substances were dissolved in $10 \mathrm{mM}$ phosphate buffer ( $\mathrm{pH} 7.2$ ) containing $140 \mathrm{~mm} \mathrm{NaCl}$ and injected into the lateral ventricle at the rate of $5 \mu \mathrm{l}$ per min. The total volume injected was always $10 \mu l$.

\section{Effect of tonin on drinking}

Experiments always began at 1 p.m. Tonin, which had been highly purified from rat submaxillary glands (Demassieux et al., 1976), was administered through the cannulae in doses of $1 \mu \mathrm{g}$ and $10 \mu \mathrm{g}$. Four $\mu \mathrm{g}$ of $\left[\mathrm{Sar}^{1}-\mathrm{Ala}^{8}\right]$ angiotensin II (P113, Eaton) or $15 \mu \mathrm{g}$ of the nonapeptide converting enzyme inhibitor (pGluTrp-Pro-Arg-Pro-Gln-Ile-Pro-Pro-OH, Beckman)was injected intraventricularly, stimultaneously with $10 \mu \mathrm{g}$ of tonin. Those in the control group were injected just $10 \mu l$ of the buffer. The volume of water drunk in the $1 \mathrm{hr}$ period following the injection was recorded. Seven rats were examined in each group.

\section{Effect of tonin on blood pressure}

The rats were anesthetized with pentobarbital sodium $(50 \mathrm{mg} / \mathrm{kg}$, i.p.). After tracheotomy, the carotid artery was cannulated and arterial blood pressure was continuously recorded using a Hewlett-Packard transducer and recorder. Ten $\mu \mathrm{g}$ of tonin was injected into the lateral ventricle. Fifteen $\mu \mathrm{g}$ of the converting enzyme inhibitor and $12 \mu \mathrm{g}$ of $\left[\mathrm{Sar}^{1}-\mathrm{Ala}^{8}\right]$ angiotensin II were administered in the same way as in the drinking experiments. In preliminary experiments, it was observed that either the buffer alone, the converting enzyme inhibitor, or [Sar $\left.{ }^{1}-\mathrm{Ala}^{8}\right]$ angiotensin II in the doses used in this experıment did not induce a significant change in blood pressure. Six rats were examined in each experiment.

\section{[In vitro experiments]}

Eight rats were anesthetized with sodium pentobarbital $(50 \mathrm{mg} / \mathrm{kg}$, i.p.). After performing a thoracotomy and a large incision in the right ventricle of the heart to drain off the incoming venous blood, the buffer $(145 \mathrm{~mm} \mathrm{NaCl}$ in $5 \mathrm{mM}$ phosphate buffer, $\mathrm{pH}=7.4$ ) was quickly infused into the left ventricle of the heart until the brain was bloodless. The rats were decapitated and the whole brain was extracted and weighed. The whole brain was homogenized in the same ice-cold buffer $(1 \mathrm{~g} / 2 \mathrm{ml})$ by a Polytron homogenizer. The homogenate was centrifuged at $4^{\circ} \mathrm{C}$ for $15 \mathrm{~min}$ at 5000 r.p.m. The supernatant was diluted 25 times with the same buffer. $0.8 \mathrm{~m} l$ of the diluted supernatant was incubated at $37^{\circ} \mathrm{C}$ for $90 \mathrm{~min}$ with $10 \mu \mathrm{g}$ of purified tonin in the presence of $10^{-3} \mathrm{M}$ of DFP (diisopropylfluorophosphate, Aldrich) and EDTA (ethylenediaminetetraacetic acid, Fisher). The total volume per tube was $1 \mathrm{~m} l$ and the final $\mathrm{pH}$ was 6.8 . The supernatant was also incubated without tonin in the presence of DFP and EDTA. After the incubation angiotensin II was measured by a specific radioimmunoassay which had been developed in Boucher's laboratory (Gutkowska et al., unpublished work). The standard curve of angiotensin II was not interfered by the supernatant. In preliminary experiments angiotensin II ( $1 \mathrm{ng}$ per tube) was incubated with the supernatant, DFP and EDTA, and we confirmed that more than $95 \%$ of angiotensin II added to the supernatant was detected after the incubation (90 $\mathrm{min})$.

Results are expressed as the mean \pm SEM. Statistical evaluation was performed with the Student's $t$ test.

\section{Results}

Effect of tonin on water drinking.

Intraventricular administration of tonin in doses of $1 \mu \mathrm{g}$ and $10 \mu \mathrm{g}$ significantly stimulated water drinking in rats $(\mathrm{p}<0.05$ and $\mathrm{p}<0.02$ respectively, Fig. 1). The latency of this response was around $7 \mathrm{~min}$. [Sar ${ }^{1}$ $-\mathrm{Ala}^{8}$ ] angiotensin II, when simultaneously injected with tonin, significantly inhibited the drinking response $(\mathrm{p}<0.05)$, whereas the converting enzyme inhibitor in a dose of $15 \mu \mathrm{g}$ did not affect the tonin induced water drinking.

Effect of tonin on blood pressure.

Intraventricular administration of tonin in a dose of $10 \mu \mathrm{g}$ consistently increased arterial blood pressure (Table 1). Typical examples are shown in Fig. 2. The increase in blood pressure started as soon as the injection of tonin was finished and reached the maximum response in 4-8 min. We observed that this response was prolonged, lasting at least $30 \mathrm{~min}$. The converting enzyme inhibitor in a dose of $15 \mu \mathrm{g}$ did not inhibit this effect of tonin. [Sar $\left.{ }^{1}-\mathrm{Ala}^{8}\right]$ angiotensin II in a dose of $12 \mu \mathrm{g}$ almost completely abolished the tonin induced increase in blood pressure. Tonin substrate in the brain homogenate.

$19.0 \pm 0.4 \mathrm{ng}$ of angiotensin II per $\mathrm{g}$ wet weight of tissue was generated when the brain homogenate was incubated with tonin in the presence of enough DFP and EDTA 


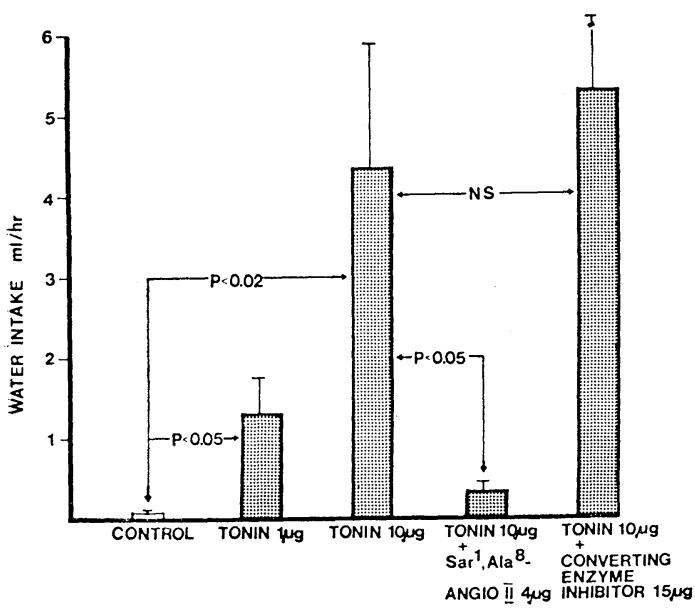

Fig. 1. Effect of intraventricular administration of tonin on water drinking. [Sar $\left.{ }^{1}-\mathrm{Ala}^{8}\right]$ angiotensin II and the converting enzyme inhibitor were administered simultaneously with tonin. Water intake in the $1 \mathrm{hr}$ period following the injection was recorded. Seven rats were examined in each group. Values represent the mean \pm SEM. Statistical evaluation was performed with the Student's unpaired $t$-test.
EFFECT OF INTRAVENTRICULAR INJECTION OF TONIN

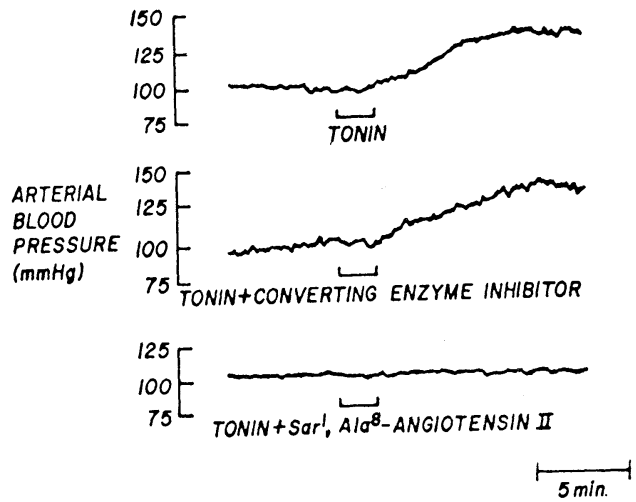

Fig. 2. Effect of intraventricular administration of tonin $(10 \mu \mathrm{g})$, tonin $(10 \mu \mathrm{g})+$ converting enzyme inhibitor $(15 \mu \mathrm{g})$, and tonin $(10 \mu \mathrm{g})+\left[\mathrm{Sar}^{1}-\mathrm{Ala}^{8}\right]$ angiotensin II $(12 \mu \mathrm{g})$ on mean blood pressure of anesthetized rats.

Table 1. Effect of intraventricular administration of tonin, tonin + converting enzyme inhibitor, and tonin $+\left[\mathrm{Sar}^{1}-\mathrm{Ala}^{8}\right]$ angiotensin II on mean blood pressure of anesthetized rats.

\begin{tabular}{|c|c|c|c|c|}
\hline Treatment & $\begin{array}{l}\text { No. of } \\
\text { animals }\end{array}$ & $\begin{array}{l}\text { Control mean blood } \\
\text { pressure }(\mathrm{mmHg})\end{array}$ & $\begin{array}{c}\text { Increase in mean blood } \\
\text { pressure }(\mathrm{mmHg})\end{array}$ & $P$ value \\
\hline Tonin $(10 \mu \mathrm{g})$ & 6 & $108.5 \pm 5.0$ & $+24.6 \pm 4.1$ & 0.005 \\
\hline $\begin{array}{l}\text { Tonin }(10 \mu \mathrm{g})+\text { Converting } \\
\text { enzyme inhibitor }(15 \mu \mathrm{g})\end{array}$ & 6 & $108.8 \pm 5.4$ & $+23.8 \pm 4.8$ & 0.005 \\
\hline $\begin{array}{l}\text { Tonin }(10 \mu \mathrm{g})+\left[\mathrm{Sar}^{1}-\mathrm{Ala}^{8}\right] \\
\text { ang1otensin II }(12 \mu \mathrm{g})\end{array}$ & 6 & $109.5 \pm 4.8$ & $+0.8 \pm 1.1$ & N.S. \\
\hline
\end{tabular}

Values represent the mean \pm SEM. $P$ values refer to comparisons with the control value.

to inhibit converting enzyme and angiotensinase in the tissue. Only $0.1 \pm 0.1 \mathrm{ng}$ of angiotensin II per $\mathrm{g}$ wet weight of tissue was detected when the brain homogenate was incubated without toin. There was a significant difference between these two values $(\mathrm{p}<0.001)$.

\section{Discussion}

Intracranially administered renin or angiotensin II causes water drinking and an increase in blood pressure, and these effects are inhibited by an antagonist of angiotensin II (Epstein et al., 1974; Solomon and Buckley, 1974; Reid and Ramsay, 1975; Kondo et al., 1979). In the present study intraventricular administration of tonin also 
consistently produced elevation of blood pressure and stimulated water drinking in rats. Since tonin is supposed not to pass the blood-brain barrier and intravenous administration of tonin has no effect on blood pressure in the rat (Boucher et al., 1978), it is supposed that intraventricularly injected tonin acted on the central nervous system. These effects of tonin were almost completely inhibited by an antagonist of angiotensin II. Our in vitro study demonstrated that angiotensin II was generated when the brain homogenate was incubated with tonin, indicating the presence of tonin substrate in the brain. These results strongly suggest that the effects of intraventricularly injected tonin, as well as those of renin, are mainly mediated by the local generation of angiotensin II in the central nervons system.

Even though the central role of angiotensin I is still controversial (Swanson et al., 1973), previous studies have reported that water drinking and increase in blood pressure induced by centrally administered renin or angiotensin I were inhibited by a converting enzyme inhibitor (Severs et al., 1973; Epstein et al., 1974; Solomon et al., 1974 ; Kondo et al., 1979). The effects of tonin, however, were not inhibited by the simultaneous intraventricular administration of a converting enzyme inhibitor. This result is consistent with the character of this enzyme which forms angiotensin II directly from a natural protein substrate. Administration of a converting enzyme inhibitor was reported not to affect the water intake caused by isoproterenol, caval ligation or water deprivation, whereas it sharply reduced drinking evoked by exogenous renin (Lehr etal., 1973). Our results might indicate the possibility that tonin plays a role in these phenomena, because some of these stimuli are known to produce tonin release from the rat submaxillary glands (Garcia et al., 1976 and 1977; Kondo, 1979).
While intravenous injection of tonin does not induce any change in blood pressure because of the presence of tonin inhibitor in plasma (Boucher et al., 1974, 1977 and 1978), recent evidence reported by Boucher's laboratory strongly indicated that tonin is important in the pathogenesis of hypertension (Kondo et al., 1977; Boucher et al., 1978; Garcia et al., 1978). Boucher et al. (1978) recently postulated that prostaglandins and sodium are major elements in activation of tonin and local formation of angiotension II within the walls of blood vessels. Although the presence of tonin in the central nervous system is under investigation, our results presented here suggest the possibility that this enzyme contributes to the maintenance of high blood pressure through the local formation of angiotensin II in the central nervous system.

\section{Acknowledgement}

We are indebted to Dr. J. Gutkowska for assistance with the angiotensin II assay. We wish to express our sincere thanks to Dr. J. Genest who supported this study in every respect. This work was supported by a group grant given by the Medical Research Council of Canada to the Multidisciplinary Research Group on Hypertension in Clinical Research Institute of Montreal, and by a grant from the Ministry of Education, Science and Culture (No. 477406).

\section{References}

Boucher, R., J. Asselin and J. Genest (1974). Circ, Res. 34 (Suppl.), 1-203.

Boucher, R., S. Demassieux, R. Garcia and J. Genest. Hypertension (edited by J. Genest, E. Koiw and O. Kuchel), McGraw-Hill, New York, p. 256 (1977).

Boucher, R., R. Garcia, J. Gutkowska, S. Demassieux and J. Genest (1978). Clin. Sci. Mol Med. 55,183 s.

Demassieux, S., R. Boucher, C. Grise and J. Genest (1976). Can. J. Biochem. 54, 788.

Donaldson, J., T. St-Pierre, J. Minnich and A. Barbeau (1971). Ibid. 49, 1217.

Epstein, A. N., J. T. Fitzsimons and A. K. Johnson (1974). J. Physiol. 238, 34p. 
Epstein, A. N., J. T. Fitzsimons and B. J. Rolls (1970). Ibid. 210, 457.

Fisher-Ferraro, C., V. E. Nahmod, D. J. Goldstein and S. Finkielman (1971). J. Exp. Med. 133, 353.

Ganten, D., A. Marquez-Julio, P. Granger, K. Hayduk, K. P. Karsunky, R. Boucher and J. Genest (1971). Am. J. Physiol. 221, 1733.

Ganten, D, and G. Speck (1978). Biochem. Pharmacol. 27, 2379.

Garcia, R., R. Boucher and J. Genest (1976). Can. J. Physiol. Pharmacol. 54, 443.

Garcia, R., R. Boucher, J. Gutkowska, K. Kondo, S. Demassieux and J. Genest (1979). Clin. Sci. Mol. Med. 54, 457.

Garcia, R., K. Kondo, B. Schölkens, R. Boucher and J. Genest (1977). Can. J. Physiol. Pharmacol. 54, 443.

Kondo, K. (1979). Jpn. Circ. J. 43, 827.

Kondo, K., R. Garcia, S. Demassieux, M. S. Manku, D. F. Horrobin, R. Boucher and J. Genest (1977).
Proc. Soc. Exp. Biol. Med. 155, 64.

Kondo, K., T. Okuno, T. Eguchi, T. Yasui, R. Nakamura and T. Saruta (1979). Endocrinol. Japon. 26, 713.

Lehr, D., H. W. Goldman and P. Casner (1973). Science 182, 1031.

Reid, I. A. and D. J. Ramsay (1975). Endocrinology 97, 536.

Severs, W. B., J. Summy-Long and A. DanielsSevers (1973). Proc. Soc. Exp. Biol. Med. 142, 203.

Smookler, H. H., W. B. Severs, W. J. Kinnard and J. P. Buckley (1966). J. Pharmacol. Exp. Ther. 153, 485.

Solomon, T. A. and J. P. Buckley (1974). J. Pharmacol. Sci. 63, 1109.

Solomon. T. A., I. Cavero and J. P. Buckley (1974). Ibid. $63,511$.

Swanson, L. W., G. R. Marshall, P. Needleman and L. G. Sharpe (1973). Brain Res. 49, 441. 